\title{
Delayed responses of an Arctic ecosystem to an extreme summer: impacts on net ecosystem exchange and vegetation functioning
}

\author{
D. Zona ${ }^{1,2}$, D. A. Lipson ${ }^{2}$, J. H. Richards ${ }^{3}$, G. K. Phoenix ${ }^{1}$, A. K. Liljedahl ${ }^{4}$, M. Ueyama ${ }^{5}$, C. S. Sturtevant ${ }^{6}$, and \\ W. C. Oechel ${ }^{2}$ \\ ${ }^{1}$ Department of Animal and Plant Sciences, University of Sheffield, Western Bank, Sheffield, S10 2TN, UK \\ ${ }^{2}$ Department of Biology, San Diego State University, San Diego, CA, USA \\ ${ }^{3}$ Department of Land, Air and Water Resources, University of California, Davis, CA, 95616-8627, USA \\ ${ }^{4}$ Water and Environmental Research Center, and International Arctic Research Center, University of Alaska Fairbanks, \\ Fairbanks, AK, USA \\ ${ }^{5}$ Graduate School of Life and Environmental Sciences, Osaka Prefecture University, Sakai, Japan \\ ${ }^{6}$ Department of Environmental Science, Policy and Management, University of California Berkeley, Berkeley, CA, USA
}

Correspondence to: D. Zona (d.zona@ sheffield.ac.uk)

Received: 9 September 2013 - Published in Biogeosciences Discuss.: 9 December 2013

Revised: 3 September 2014 - Accepted: 5 September 2014 - Published: 24 October 2014

\begin{abstract}
The importance and consequences of extreme events on the global carbon budget are inadequately understood. This includes the differential impact of extreme events on various ecosystem components, lag effects, recovery times, and compensatory processes. In the summer of 2007 in Barrow, Arctic Alaska, there were unusually high air temperatures (the fifth warmest summer over a 65 -year period) and record low precipitation (the lowest over a 65-year period). These abnormal conditions were associated with substantial desiccation of the Sphagnum layer and a reduced net Sphagnum $\mathrm{CO}_{2}$ sink but did not affect net ecosystem exchange (NEE) from this wet-sedge arctic tundra ecosystem. Microbial biomass, $\mathrm{NH}_{4}^{+}$availability, gross primary production (GPP), and ecosystem respiration ( $\left.R_{\text {eco }}\right)$ were generally greater during this extreme summer. The cumulative ecosystem $\mathrm{CO}_{2}$ sink in 2007 was similar to the previous summers, suggesting that vascular plants were able to compensate for Sphagnum $\mathrm{CO}_{2}$ uptake, despite the impact on other functions and structure such as desiccation of the Sphagnum layer. Surprisingly, the lowest ecosystem $\mathrm{CO}_{2}$ sink over a five summer record (2005-2009) was observed during the 2008 summer ( $\sim 70 \%$ lower), directly following the unusually warm and dry summer, rather than during the extreme summer. This sink reduction cannot solely be attributed to the potential damage to mosses, which typically contribute $\sim 40 \%$ of the entire ecosystem $\mathrm{CO}_{2}$ sink. Importantly, the return to a sub-
\end{abstract}

stantial cumulative $\mathrm{CO}_{2}$ sink occurred two summers after the extreme event, which suggests a substantial resilience of this tundra ecosystem to at least an isolated extreme event. Overall, these results show a complex response of the $\mathrm{CO}_{2}$ sink and its sub-components to atypically warm and dry conditions. The impact of multiple extreme events requires further investigation.

\section{Introduction}

Global increases in mean temperature (Vavrus et al., 2012) and evapotranspiration are expected to lead to drier conditions in many regions of the world (IPCC, 2013). Heat waves and warm spells are also increasing in frequency and duration in most of the world (Perkins et al., 2012), including at high latitudes (Tingley and Huybers, 2013). Large parts of Alaska and Canada have been subjected to a substantial drying over the last 50 years (as shown by the increase in the Palmer Drought Severity Index using the Penman-Monteith equation, PDSI-PM, Sheffield et al., 2012). It is very important to understand extreme weather events such as drought and warming as they may have a disproportionate impact on ecosystem structure and function compared to climate change trends, exceeding the lethal thresholds for organisms more rapidly (Marchand et al., 2006a; Jentsch et al., 2007). 
Generally, arctic ecosystems are among those experiencing the fastest relative and absolute changes in climatic conditions (IPCC, 2013), and can be highly sensitive to extreme climatic events (Bokhorst et al., 2011). It is therefore critical to understand the effect of increased climate variability on arctic tundra ecosystem functioning.

Often, warming has been connected to increased productivity in northern ecosystems (Zhou et al., 2001; Chen et al., 2006; Zhao and Running, 2010; Wookey et al., 2009; Epstein et al., 2012). This occurs, at least in part, because optimum temperatures for photosynthesis in arctic vegetation are usually higher than the observed mean temperatures (Wilson, 1957; Oechel, 1976; Tieszen, 1981). On the other hand, the impact of temperature increases on ecosystem respiration $\left(R_{\text {eco }}\right)$ can result in a net $\mathrm{C}$ release from northern ecosystems (Billings, 1982; Peterson et al., 1984; Piao et al., 2008). The occurrence of high summer temperatures might negatively affect the photosynthetic capacity of arctic plants and increase leaf mortality due to direct temperature stress and/or drying (Marchand et al., 2005, 2006a) as peatlands have been shown to be sensitive to drought (Lafleur et al., 2003; Riutta et al., 2007; Lund et al., 2012). Increased temperatures may also decrease species richness and change the composition of Arctic plant communities (Walker et al., 2006; Elmendorf et al., 2012). Additionally, warming stimulates respiratory loss and might turn the tundra ecosystems into a $\mathrm{C}$ source (Billings et al., 1982; Dorrepaal et al., 2009). It is still largely unknown how the combined changes in temperature and soil moisture (i.e., drought and heat waves) will ultimately affect ecosystems (Wu et al., 2011). This is particularly true for arctic tundra ecosystems, which present an extremely complex response to temperature and hydrological change due to the presence of permafrost. The near desert-like precipitation regime is able to sustain extensive arctic wetlands, partly due to the high soil water storage capacity and low drainage constrained from the shallow active layer (the ground that experience seasonal freeze and thaw). However, despite these factors, there is evidence that reduced precipitation can reduce the $\mathrm{CO}_{2}$ sink, at least in the more southerly of these high-latitude ecosystems, due to soil drying and increases in $R_{\text {eco }}$ (Oechel et al., 1993, 1995; Angert et al., 2005; Piao et al., 2008).

Overall, there is a need to understand how temperature and hydrological change affects high-latitude ecosystems. Therefore, in this study we investigated the impact of an extremely low precipitation and very warm summer (2007) on a wetsedge arctic tundra ecosystem in Barrow, Alaska. We hypothesized that warm and dry conditions would result in a rapid decrease in net ecosystem $\mathrm{CO}_{2}$ sink due to drought stress to vegetation and the increase in $R_{\text {eco }}$ at higher temperatures. We also hypothesized that the net ecosystem exchange (NEE), gross primary production (GPP), and $R_{\text {eco }}$ recovered to normal values immediately after the extreme event, with a return to normal weather conditions. To investigate how the entire ecosystem (larger scale) and different vegetation com- ponents (smaller scale) were affected by this extreme event, we compared NEE, GPP, and ecosystem respiration $\left(R_{\text {eco }}\right)$ to plot-scale net "moss (Sphagnum spp.) $\mathrm{CO}_{2}$ sink" (net Sphagnum exchange, NSE), vascular plant development (leaf area index, LAI), soil microbial biomass $\mathrm{C}$, and nutrient availability. Finally, to understand the resilience of this wet-sedge tundra ecosystem to this extreme event, we also investigated the response of NEE, GPP, and $R_{\text {eco }}$ during two additional growing seasons after this extreme weather event, therefore including a total record of 5 years in this study.

\section{Materials and methods}

\subsection{Study site}

The study area is located in a vegetated drained lake basin at the Barrow Environmental Observatory (BEO), about $10 \mathrm{~km}$ east of the town of Barrow, Alaska, with a basin area of about $0.3 \mathrm{~km}^{2}$. The area is characterized by low elevation, moderate slopes (Brown, 1967), the presence of continuous permafrost with a seasonal thaw depth of up to $\sim 40 \mathrm{~cm}$ (Hinkel et al., 2001), and wet-sedge tundra vegetation (Brown, 1967). This tundra vegetation is composed of Carex aquatilis, Eriophorum vaginatum, and Dupontia fisheri, and is dominated by mosses (mostly Sphagnum spp.) which are about $80 \%$ of the living biomass (Zona et al., 2009; 2011). Long-term average meteorological conditions of the site are reported in Table 1.

\subsection{Eddy-covariance measurements}

Three eddy-covariance (EC) towers were installed at the beginning of summer 2005 for a large-scale manipulative experiment (Zona et al., 2009, 2012). The eddy-covariance tower included a Gill WindMasterPro sonic anemometer (Gill Instruments Ltd., Lymington, Hampshire, UK), and an open path LI-7500, placed at about $1.6 \mathrm{~m}$ above the ground (Zona et al., 2009). For the present study, data from the control (south) section not subjected to manipulations from 2005-2008 were used (south tower, $71^{\circ} 16^{\prime} 51.17^{\prime \prime} \mathrm{N}$, $156^{\circ} 35^{\prime} 47.28^{\prime \prime} \mathrm{W}, \sim 4.6 \mathrm{~m}$ a.s.l.). As the south section was also subjected to an increased water table at the end of July 2009, the cumulative $\mathrm{CO}_{2}$ uptake for that season is included until the end of July. In contrast to the previous published studies which mostly investigated the impact of flooding on $\mathrm{CO}_{2}$ and $\mathrm{CH}_{4}$ fluxes (Zona et al., 2009, 2012), this study focuses on the impact of a naturally occurring extreme event on net ecosystem exchange (NEE), gross primary production (GPP), ecosystem respiration ( $R_{\text {eco }}$ ), net Sphagnum $\mathrm{CO}_{2}$ exchange (NSE), leaf area index (LAI), microbial biomass C, and ammonium $\left(\mathrm{NH}_{4}^{+}\right)$in soil pore water.

Flux processing of the $\mathrm{CO}_{2}$ fluxes, gap-filling, quality control, and footprint analysis followed standard procedures using EdiRe (http://www.geos.ed.ac.uk/abs/research/ micromet/EdiRe/), using a cross-covariance function for estimating the time delays, double rotations of the wind 
components ( $w$, and $v$ ), and the Webb-Pearman-Leuning correction (Webb et al., 1980) for the $\mathrm{CO}_{2}$ fluxes. More details are described in Zona et al. $(2009,2012)$ and in Sturtevant et al. (2012). As we previously reported (Zona et al., 2012), the $u^{*}$ threshold used was set to $0.1 \mathrm{~m} \mathrm{~s}^{-1}$, and the footprint analyses (Hsieh et al., 2000; Kljun et al., 2004) performed on the eddy-covariance fluxes showed that most $(\sim 90 \%)$ of the fluxes corresponded to a fetch $80 \mathrm{~m}$ upwind from the tower. The percent data coverage of the NEE data was $47 \%$ in $2005,43 \%$ in $2006,55 \%$ in $2007,45 \%$ in 2008 , and $46 \%$ in 2009 . This data coverage is fairly typical for eddy-covariance towers in arctic and boreal ecosystems; data coverage from these northern sites is about $15 \%$ in the winter (Oechel et al., 2014), and ranges between 33$60 \%$ in the summer, with a few sites in the boreal forest with $>80 \%$ data coverage (Ueyama et al., 2013). The flux uncertainties and gap-filling were performed using standard online methodologies, as used in Fluxnet (http://www.bgjena. mpg.de/ MDIwork/eddyproc/, and in Reichstein et al., 2005 and Lasslop et al., 2010). The flux partitioning for estimating GPP and $R_{\text {eco }}$ was performed according to Runkle et al. (2013).

\subsection{Environmental conditions}

Soil moisture, soil temperature at different depths (surface, 5, 10, 20, and $30 \mathrm{~cm}$ ), air temperature, relative humidity, photosynthetically active radiation (PAR), and net radiation were measured near the EC tower, as described in Zona et al. (2009, 2012). Surface temperature was estimated from the infrared radiation emitted from the vegetation surface and collected with a Apogee infrared sensor (Apogee Instruments, Inc. ${ }^{\mathrm{TM}}$, Logan, Utah, USA) pointing towards the main footprint of the EC towers (Zona et al., 2009). Diffuse radiation was measured using a Sunshine Sensor (Delta-T Devices, Cambridge, UK). The sunshine status threshold is $120 \mathrm{~W} \mathrm{~m}^{-2}$ (therefore when the diffuse radiation was below this value, the sensor reported a diffuse radiation equal to zero). These environmental conditions were assumed to be fairly representative of the general environment experienced by the mosses and were used for the statistical analysis.

Potential evapotranspiration (PET) during 1999-2009 was calculated using the Penman-Monteith equation (Monteith, 1975) using field measurements from the EC tower (above) and from Harazono et al. (2006) assuming a ground heat flux of $10 \%$ of net radiation. Long-term records (1949-2013) of daily precipitation and air temperature were retrieved from the National Climatic Data Center (NCDC) archive for Barrow Airport (STN 700260, WBAN 27502, http://www. ncdc.noaa.gov/cdo-web/\#t=firstTabLink). Precipitation was adjusted for undercatch according to Yang et al. (1998). Long-term (1999-2009) incoming solar radiation (direct and diffuse) was obtained from the Atmospheric Radiation Measurement (ARM) program (http://ncvweb.archive.arm.gov/). The start date of summer (end of snow melt) was defined by visual inspection at the site and by the characteristic increase in net radiation (1999-2003 and 2005-2006), peak runoff measurements (2007), ablation measurements (2008 and 2009), and the resulting calibration of the temperature and wind index degree-day method for 2004. The thaw depth was measured with a lower intensity (at 12,21, and 20 points across the $200 \mathrm{~m}$ transect from the tower) in 2005-2007, then increased to 100 points (Zona et al., 2012) in 2008, and 2009.

Ammonium $\left(\mathrm{NH}_{4}^{+}\right)$in soil pore water and soil microbial biomass $\mathrm{C}$ were measured as described in Lipson et al. (2012). Briefly, soil pore water was collected from 18 locations every $\sim 20 \mathrm{~m}$ across the same transects where the water table and thaw depth measurements were performed, using Eijkelkamp Rhizon soil moisture samplers, and $\mathrm{NH}_{4}^{+}$was measured using a phenolate/hypochlorite color assay. Soil cores were collected to a depth of $15 \mathrm{~cm}$ from a total of 36 locations every $\sim 25 \mathrm{~m}$ across these transects, and soil microbial biomass $\mathrm{C}$ was measured using chloroform fumigationextraction followed by analysis with an Mn(III)-sulfuric acid assay.

\subsection{Sphagnum water content, net Sphagnum $\mathrm{CO}_{2}$ exchange (NSE)}

Water content in the Sphagnum layer was determined gravimetrically in summer 2006 and 2007 (Zona et al., 2011). Four samples of the first $2 \mathrm{~cm}$ of the Sphagnum layer (about $10 \mathrm{~cm}$ diameter) were removed at each measurement date using a sharp scissor, sealed inside aluminium cans, and returned to the laboratory for weighing and drying. Net Sphagnum $\mathrm{CO}_{2}$ exchange (NSE) measurements were performed weekly by removing eight samples $(4 \mathrm{~cm}$ in diameter) in each of three different plots (every about 50-70 m) across a $200 \mathrm{~m}$ transect upwind from the EC tower, including the first $2 \mathrm{~cm}$ of the moss mat. The eight samples in each of these three plots were sampled at 1-2 $\mathrm{m}$ distance from each other. For these measurements, a LI-6400 portable photosynthetic system (LI-COR, Lincoln, Nebraska, USA) and a modified conifer chamber (Zona et al., 2011) were used. These measurements represented the net $\mathrm{CO}_{2}$ exchange in the green photosynthetic layer of Sphagnum; the term net Sphagnum $\mathrm{CO}_{2}$ exchange is used for consistency with a previous published paper (Zona et al., 2011).

\subsection{Leaf area index (LAI)}

The leaf area index (LAI) of vascular plants was measured weekly with an optical plant canopy analyzer (LAI-2000, LI-COR, Lincoln, Nebraska, USA) across the $200 \mathrm{~m}$ transect upwind from the EC tower in summer 2006 and 2007. In summer 2006, LAI was estimated from 7 July to $30 \mathrm{Au}-$ gust at three different points across this transect (three repetitions in each of these three locations for a total of nine measurements for each measuring date). In summer 2007, LAI was estimated from 22 June to 28 August in the same 
Table 1. Meteorological and hydrological conditions at the Barrow Environmental Observatory, Alaska, for the indicated periods in 20052009 compared to long-term means. Summer 2007 experienced the lowest precipitation over the period 1949-2009 (followed by 1991, $19 \mathrm{~mm}$ ) and was the fifth warmest summer. Values represent end-of-snowmelt to the end of August unless otherwise stated. Precipitation values in parentheses 2005-2009 represent the total for June through August.

\begin{tabular}{|c|c|c|c|c|c|c|c|}
\hline Variable & 2005 & 2006 & 2007 & 2008 & 2009 & $\begin{array}{l}\text { Long- } \\
\text { term }\end{array}$ & $\begin{array}{r}\text { Long-term } \\
\text { period }\end{array}$ \\
\hline $\begin{array}{l}\text { Mean summer air } \\
\text { temperature, }{ }^{\circ} \mathrm{C}^{\mathrm{a}}\end{array}$ & 3.3 & 2.9 & 5.4 & 3.3 & 3.8 & 3.2 & 1949-2013 \\
\hline $\begin{array}{l}\text { Cumulative incoming summer } \\
\text { solar radiation, MJ }\end{array}$ & 1333 & 1311 & 1542 & 1344 & 1376 & 1327 & 1999-2009 \\
\hline $\begin{array}{l}\text { Total summer diffuse solar } \\
\text { radiation, MJ }\end{array}$ & 733 & 850 & 774 & 859 & 917 & 824 & 1999-2009 \\
\hline $\begin{array}{l}\text { Snow water equivalent } \\
(\mathrm{SWE}), \mathrm{mm}^{\mathrm{b}}\end{array}$ & 100 & 138 & 95 & 155 & 127 & 120 & 1995-2009 \\
\hline $\begin{array}{l}\text { Summer precipitation, } \\
\mathrm{mm}^{\mathrm{c}}\end{array}$ & $\begin{array}{r}74 \\
(86)^{\mathrm{a}}\end{array}$ & $\begin{array}{r}61 \\
(65)^{\mathrm{a}}\end{array}$ & $\begin{array}{r}13 \\
(13)^{\mathrm{a}}\end{array}$ & $\begin{array}{r}56 \\
(67)^{\mathrm{a}}\end{array}$ & $\begin{array}{r}89 \\
(91)^{\mathrm{a}}\end{array}$ & $72^{\mathrm{a}}$ & 1949-2013 \\
\hline $\begin{array}{l}\text { Potential summer } \\
\text { evapotranspiration (PET), mm }\end{array}$ & 165 & 134 & 208 & 147 & 155 & 157 & 1999-2009 \\
\hline $\begin{array}{l}\text { Precipitation-PET, } \\
\mathrm{mm}\end{array}$ & -91 & -72 & -194 & -91 & -66 & -86 & 1999-2009 \\
\hline
\end{tabular}

\footnotetext{
a Represents June through August.

b SWE is from CALM (Brown et al., 2000) snow depth measurements with snow density set to $0.32 \mathrm{~g} \mathrm{~cm}^{-3}$.

c Adjusted according to Yang et al. (1998).

${ }^{\mathrm{d}}$ Penman-Monteith method (Monteith, 1975) assuming a ground heat flux of $10 \%$ of the net radiation.
}

transect at 11 locations (one repetition in each of these locations for a total of 11 measurements per sampling date). LAI of the three most abundant species (Carex aquatilis, Dupontia fisheri, Eriophorum spp.) was also measured directly by destructive biomass sampling performed in mid-August 2006 (Olivas et al., 2011; Zona et al., 2011). All leaves of these species were scanned next to an object of known area as described in Olivas et al. (2011), and the total leaf area of these three species was divided by the plot area, giving a reasonable comparison to LAI measured with the LAI-2000 (the difference in these estimates was $\sim 9 \%$; Zona et al., 2011).

\subsection{Statistical analyses}

One-way ANOVA and Bonferroni post hoc test (SYSTAT 13, Systat Software Inc., Chicago, IL, USA) were used to test if NEE, GPP, $R_{\text {eco }}$, NSE, and LAI were significantly different between the summers of 2006 and 2007, and if the $\mathrm{NH}_{4}^{+}$in soil pore water and soil microbial biomass $\mathrm{C}$ were different among the years (2006-2009). For NEE, GPP, $R_{\text {eco }}$, NSE, and LAI, these tests were performed for the entire data set divided into intervals (12-30 June, 1-26 July, 27 July-16 August, 17-30 August). These intervals (with slightly different lengths) were selected because they correspond to the typical phases of vegetation development during the growing season in the Arctic (early season after snow melt: 12-30 June; peak season with maximum vegetation development: 1-26 July; late season after 27 July until the end of August). The late season period was divided into two sub-periods (27
July-16 August, 17-30 August) after we noticed that the environmental conditions changed substantially on 16 August 2007 when rainfall suddenly increased the water table and moisture content (see Results).

\section{Results}

\subsection{Environmental conditions, Soil Microbial Biomass C, and Soil Water $\mathrm{NH}_{4}^{+}$}

From visual inspection, snow melt occurred on 12-13 June in 2005, on 13 June in 2006, on 10-11 June in 2007, and on 12 June in 2008, and on 9 June in 2009. These estimates were in fairly good agreement with the end of snowmelt estimated from the degree-day method (which was calibrated with ablation measurements in 2008-2009), estimating a snow melt on 15 June (2005), 11 June (2006), 9 June (2007), 9 June (2008), and 5 June (2009). This second method was used to estimate the long-term (1999-2009) snow melt average, which was 10 June. Monthly air temperatures from NOAA's long-term record showed that the period of July to the end of August 2007 was the warmest over the 129-year record on the North Slope of Alaska (Jones et al., 2009). In Barrow, the period from the beginning of June until the end of August 2007 represented the lowest precipitation during a 65-year period (1949-2013, Table 1). At our site, the mean air temperature $\left(5.4^{\circ} \mathrm{C}\right)$ in summer 2007 was two degrees higher than the long-term mean of $3.2^{\circ} \mathrm{C}$, and the surface temperature more than $10^{\circ} \mathrm{C}$ higher than the previous colder and 
wetter summer (Supplement Fig. S1). Additionally, the total summer precipitation was $13 \mathrm{~mm}$, which is less than $20 \%$ of the long-term average $(72 \mathrm{~mm})$ (Table 1$)$. This air temperature increase is double the average temperature increases obtained with warming experiments using open top chambers across the Arctic (Bokhorst et al., 2013), and a $10^{\circ} \mathrm{C}$ surface temperature increase is similar to what was reported in Marchand et al. (2006b). The atypical weather of summer 2007 was associated with much higher evaporative demand, much higher difference between precipitation and potential evapotranspiration (P-PET), higher cumulative incoming solar radiation and lower diffuse radiation than the long-term average (Table 1), and higher vapor pressure deficit (VPD) (Liljedahl et al., 2011). The summer of 2007 also had lower soil moisture (Supplement Figs. S1 and S2) and higher radiation than the more typical summers (Table 1) and occasional periods of high VPD with high solar radiation and low diffuse radiation (Supplement Fig. S3).

Thaw depth reached about $-30 \pm 3 \mathrm{~cm}$ on 24 August $2005(n=21),-30 \pm 3 \mathrm{~cm}(n=12)$ on 24 August 2006, $-26 \pm 2 \mathrm{~cm}$ on 2 September $2007(n=12),-29 \pm 2 \mathrm{~cm}$ at the 27 August $2008(n=51)$, and $-31 \pm 3 \mathrm{~cm}$ on the 19 August $2009(n=51)$. The water table was about $0 \pm 1 \mathrm{~cm}$ on 24 August 2006, $-9 \pm 1 \mathrm{~cm}$ on 25 August 2007, $-4 \pm 3$ on 27 August 2008, $-11 \pm 7 \mathrm{~cm}$ on the 29 July 2009 (before the beginning of any water pumping, see methods). The warmer conditions of summer 2007 stimulated the soil microbial community, affecting decomposition rates - which in turn increased nutrient availability for the vegetation (Fig. 1) and respiratory loss (Fig. 2). Microbial biomass more than doubled in summer 2007 (Fig. 1), consistent with the increase in respiratory loss (Fig. 3). In the summer after the extreme summer, both microbial biomass and $\mathrm{NH}_{4}^{+}$decreased substantially following the temperature decrease.

\subsection{NEE, GPP, and $R_{\text {eco }}$, NSE, and LAI}

The higher temperatures in summer 2007 led to an early productivity of the ecosystem, as shown by the rapid $\mathrm{CO}_{2}$ sink right after snow melt as compared to the previous summer (Fig. 2a, b). During the beginning of the summer, GPP was significantly higher in 2007 than in 2006 (Table 2). Even though the ecosystem was a net $\mathrm{CO}_{2}$ sink in the early season, we measured $\mathrm{CO}_{2}$ loss from the Sphagnum layer (i.e., positive NSE) (Fig. 2c) during this period.

During peak season (1-25 July), mosses were responsible for a substantial $\mathrm{CO}_{2}$ sink both in 2007 and in the previous "normal" summer 2006 (Fig. 2c and Table 2). During the abnormally warm summer of 2007, surface temperatures, even if much higher $\left(>10^{\circ} \mathrm{C}\right)$ than the previous year (Supplement Fig. S1), were below or at the optimum for photosynthesis in Sphagnum (between about $20^{\circ} \mathrm{C}$, Harley et al., 1989, and $25^{\circ} \mathrm{C}$, Gerdol and Vicentini, 2011). Peak season NEE in the warm and dry 2007 was not significantly different from 2006 (Fig. 2b, Table 2) despite the major differences in environ-
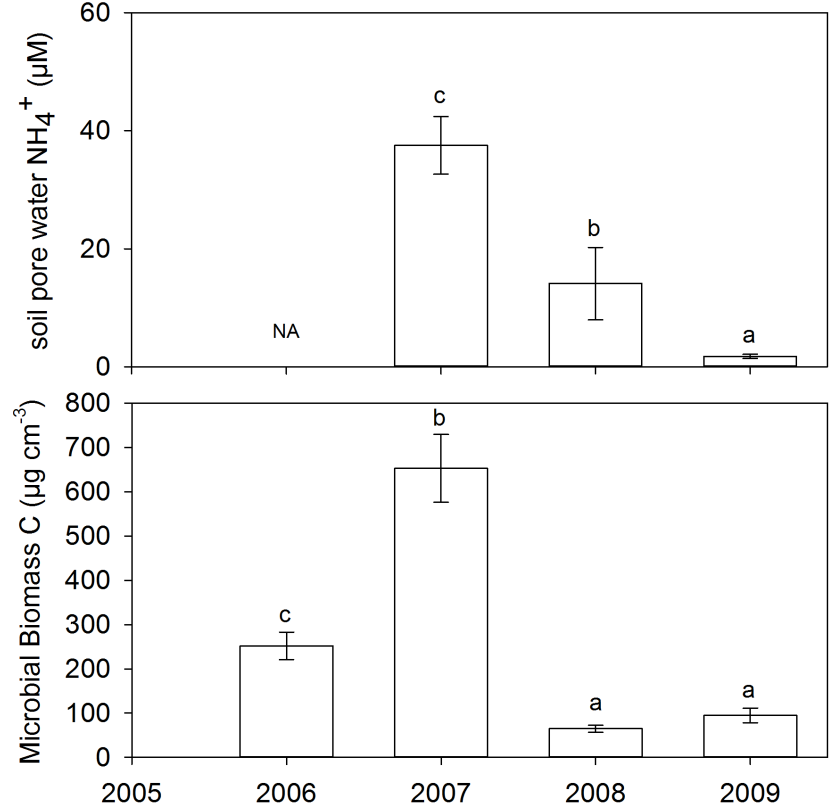

Figure 1. Soil pore water $\mathrm{NH}_{4}^{+}$and microbial biomass $\mathrm{C}$ in 18 and 36 locations respectively across the research site. Indicated are averages and standard errors of the mean. NA means no data available.

mental conditions. However, the similar NEE was the result of very different GPP and $R_{\text {eco }}$, both of which were significantly higher in 2007 compared to 2006 (Table 2).

In contrast, later in the season, the $\mathrm{CO}_{2}$ sink in 2007 was lower than in 2006 (Fig. 2b), even if not statistically different (Table 2). The observed decrease in $\mathrm{CO}_{2}$ sink later in the season in 2007 coincided with the water limitation of the C assimilation from Sphagnum (as shown by the positive NSE, Fig. 2c), with Sphagnum water content below $900 \%$ DW (Supplement Figs. S3 and S4). The water limitation of the Sphagnum $\mathrm{CO}_{2}$ sink was confirmed by the significant correlation between NSE and Sphagnum water content (WC) in July-August $2007\left(r^{2}=0.76 ; P<0.05\right)$, a water limitation that was not observed in 2006 (Zona et al., 2011). The early season light stress and late season water stress (Supplement Fig. S4) were associated with a seasonal NSE close to zero in summer 2007.

During the final part of the season (17-31 August 2007), the Sphagnum layer showed a partial recovery, as shown by the $\mathrm{C}$ assimilation of NSE from 17-30 August (Fig. 2c). This occurred after a major rainfall in mid-August $(9 \mathrm{~mm})$, which increased Sphagnum WC (Supplement Fig. S3).

The LAI of vascular plants (average $\pm \mathrm{SD}$ : $0.45 \pm 0.10 \mathrm{~m}^{2} \mathrm{~m}^{-2}$ and $0.40 \pm 0.12 \mathrm{~m}^{2} \mathrm{~m}^{-2}$ from beginning of July to the end of August in 2006 and 2007, respectively, Fig. 2d) was not significantly different between two summers of any of the tested periods (Table 2). Summer 2006 and 2007 also presented a similar peak normalized difference vegetation index (NDVI) (Olivas et al., 2010). 
Table 2. Statistical results for the significance of the difference of net ecosystem exchange (NEE, $F$ ratio $=44.8$, d.f. $=7,3788$ ), gross primary production $(\mathrm{GPP}, F$ ratio $=214$, d.f. $=7,7768)$, ecosystem respiration $\left(R_{\mathrm{eco}}, F\right.$ ratio $=694.7$, d.f. $\left.=7,7768\right)$, net $S p h a g n u m$ exchange $(\mathrm{NSE}, F$ ratio $=2.96$, d.f. $=7,12$ ), and leaf area index (LAI, $F$ ratio $=1.5$, d.f. $=5,99$ ), between 2006 and 2007 (one-way ANOVA including type III adjusted sums of squares, and Bonferroni post hoc test) for the indicate periods; NA indicates no data available. Descriptive data on the flux $\mathrm{C}$ components are displayed in Fig. 2.

\begin{tabular}{lccccc}
\hline Period & NEE & GPP & $R_{\text {eco }}$ & NSE & LAI \\
\hline 12-30 June & $P<0.001$ & $P<0.001$ & $P=1$ & $P=1$ & NA \\
1-26 July & $P=0.46$ & $P<0.001$ & $P<0.001$ & $P=1$ & $P=1$ \\
27 July-16 August & $P=0.408$ & $P=0.008$ & $P<0.001$ & $P=0.188$ & $P=1$ \\
17-30 August & $P=0.568$ & $P<0.001$ & $P<0.001$ & $P=1$ & $P=1$ \\
\hline
\end{tabular}

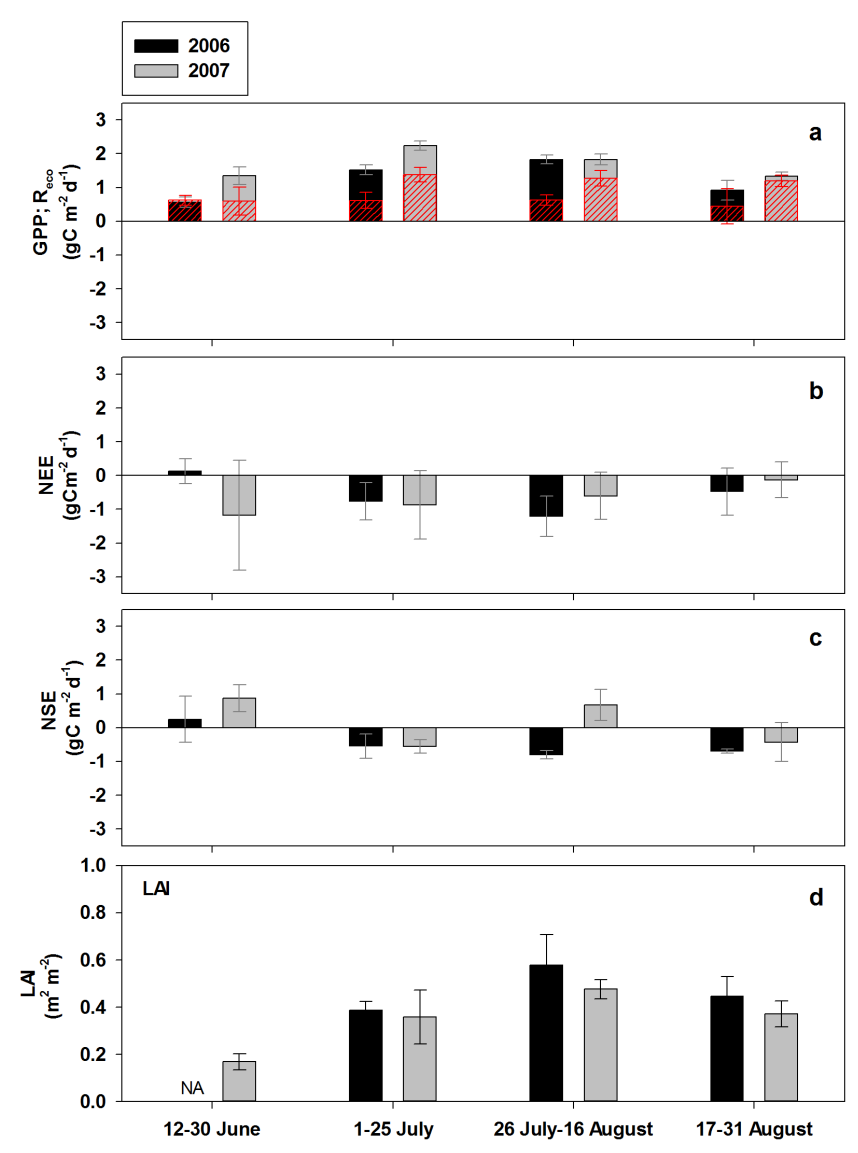

Figure 2. Ecosystem functioning during summer in 2006 and 2007 at the Barrow Environmental Observatory, Alaska; (a) gross primary production (GPP) and ecosystem respiration $\left(R_{\text {eco }}\right.$ displayed as red hatched areas), (b) net ecosystem exchange (NEE), (c) net Sphagnum exchange (NSE), and (d) leaf area index (LAI), averaged for each of the indicated periods. Error bars are standard errors of the mean (for all samples). NA means no data available. Negative NEE and NSE represent a $\mathrm{CO}_{2}$ sink, while positive values represent $\mathrm{C}$ loss. The significance of differences between 2006 and 2007 values are reported in Table 2 . Error bars for NEE, $R_{\text {eco }}$, and GPP are propagated flux uncertainties estimated by online gapfilling (http://www.bgjena.mpg.de/ MDIwork/eddyproc/).
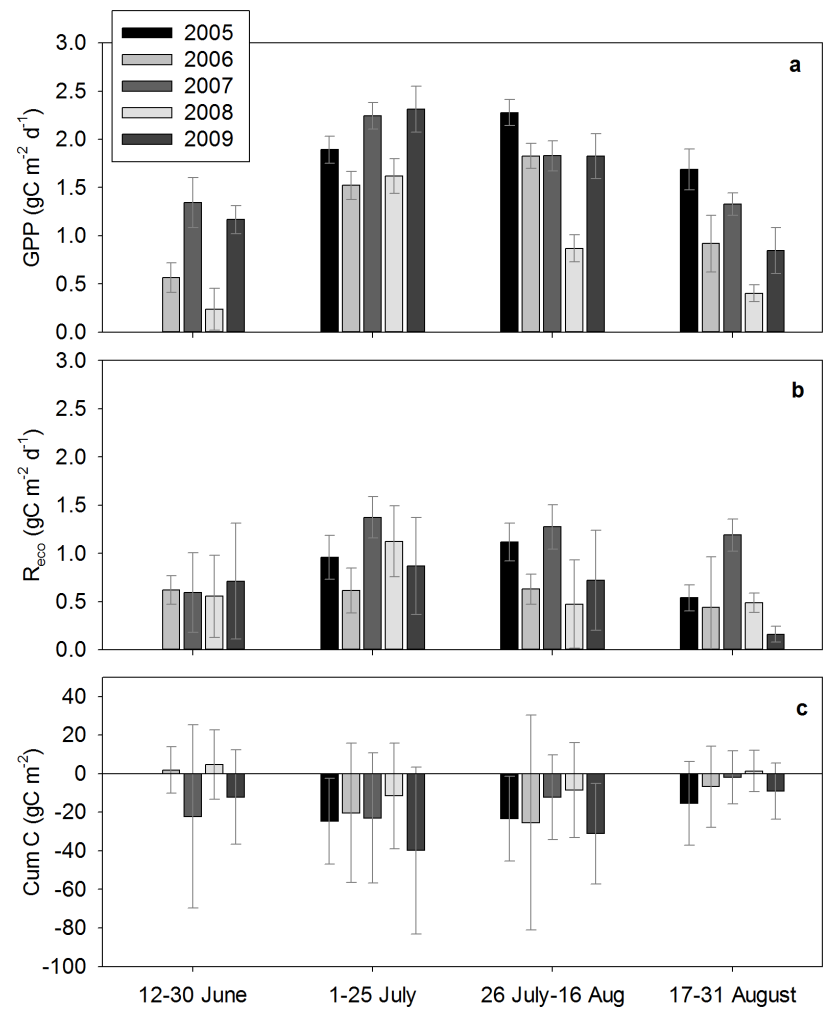

Figure 3. Gross primary production (GPP), ecosystem respiration $\left(R_{\text {eco }}\right)$, and net ecosystem exchange (NEE), for 2005-2009 during the indicated periods. Error bars for NEE, $R_{\mathrm{eco}}$, and GPP are propagated flux uncertainties estimated by online gap-filling (http: //www.bgjena.mpg.de/ MDIwork/eddyproc/) for the indicated periods.

As the top of the Sphagnum layer is mostly brown (Zona et al., 2011), NDVI mainly captured the vascular plant development. Surprisingly, total $\mathrm{CO}_{2}$ sink during the extreme summer $2007\left(59 \mathrm{~g} \mathrm{CO}_{2} \mathrm{~m}^{-2}\right)$ was fairly similar to previous summers. A total $\mathrm{CO}_{2}$ sink $51 \mathrm{~g} \mathrm{CO}_{2} \mathrm{~m}^{-2}$ was observed in summer 2006; and in summer 2005 the ecosystem was a $\mathrm{CO}_{2}$ sink of $64 \mathrm{~g} \mathrm{C} \mathrm{m}^{-2}$, but the eddy-covariance tower started collecting data 2 weeks later (1 July instead of mid-June). The first 2 weeks of June are usually a moderate 
$\mathrm{CO}_{2}$ source $\left(2.3 \mathrm{~g} \mathrm{C} \mathrm{m}^{-2}\right.$ in 2006), which suggests that the total summertime $\mathrm{CO}_{2}$ sink in 2005 was probably slightly lower than the measured value and therefore, fairly similar to both 2006 and 2007 summers. On the contrary, summer 2008, which experienced air temperatures and solar radiation near the long-term average (although slightly below normal summer precipitation), presented the lowest cumulative $\mathrm{CO}_{2}$ gain $\left(14 \mathrm{~g} \mathrm{CO}_{2} \mathrm{~m}^{-2}\right)$; less than $70 \%$ that of summer $2006\left(51 \mathrm{~g} \mathrm{CO}_{2} \mathrm{~m}^{-2}\right)$. This reduction exceeded the typical contribution of mosses to the overall summer season $\mathrm{CO}_{2}$ sink (estimated to be about $40 \%$ by Zona et al., 2011). The cumulative $\mathrm{CO}_{2}$ sink was again substantial in summer 2009 (55 $\mathrm{g} \mathrm{CO}_{2} \mathrm{~m}^{-2}$ from 12 June until 28 July).

To estimate the recovery of this wet sedge tundra ecosystem to the 2007 extreme summer event, we compared GPP, $R_{\text {eco }}$, and cumulative $\mathrm{CO}_{2}$ uptake during the growing season 2005-2009. Total $\mathrm{CO}_{2}$ uptake showed a five-year minimum in summer 2008 (Fig. 3), which was not the result of a higher $R_{\text {eco }}$ (Fig. 3), but of a lower GPP (Fig. 3), the minimum over the entire five-year record. During summer 2009, cumulative $\mathrm{CO}_{2}$ uptake and GPP recovered to similar values to the summers previous to the extreme event.

\section{Discussion}

The higher evaporative demand of the abnormal 2007 summer affected the Sphagnum layer, as shown by the substantial moss desiccation. Sphagnum mosses do not have roots and rely on capillary transport of water between and within the short structure of their photosynthetic tissues (Price et al., 2009), and are therefore very sensitive to surface moisture conditions. These results suggest that a combination of unusually warm temperatures and high radiation input (both resulting in a greater evaporative demand) can negatively affect the functioning of a dominant vegetation component (e.g., Sphagnum spp.) of this wet-sedge tundra ecosystem if precipitation (rainfall and dewfall) is also low.

However, even though visual inspection showed a substantial desiccation of the moss mat (Supplement Fig. S5), we do not think that our NSE measurements were able to accurately quantify the actual percentage of the Sphagnum affected by and/or able to recover from the water stress. Importantly, the large variability and the small sample size of the NSE measurements resulted in no statistical difference in NSE between 2006 and 2007 for any of the periods tested when the stringent Bonferroni adjustment was used. Overall, the substantial desiccation of the Sphagnum mat towards the end of summer 2007 (Supplement Fig. S5) was consistent with the observed water limitation of NSE (Supplement Fig. S4) and the decrease in ecosystem net $\mathrm{CO}_{2}$ sink rates (Fig. 2). Vascular plants were not negatively affected by this unusual weather, as shown by the similar LAI in both 2006 and 2007 (Fig. 2). We therefore conclude that the substantial $\mathrm{CO}_{2}$ sink during the last 2 weeks of June (negative NEE,
Fig. 2b) was due to an early activation of vascular plants in 2007, even though the LAI was still relatively low during this period (Fig. 2d). Vascular plant productivity then would also be supported by the soil water resulting from the relatively impermeable permafrost that would have impaired further lowering of the water table. With the release of meltwater from ice in the active layer, this perched water table provided a continuous supply of water to the roots of vascular plants that was unavailable to the mosses (i.e., water depth at $>10 \mathrm{~cm}$ ) when precipitation was sparse. This buffering water supply allowed the vascular plants to retain access to soil water. This also suggests that a drier climate could favor vascular plants and more negatively affect mosses in the Arctic due to relative desiccation of the mosses (Elmendorf et al., 2012; Lund et al., 2012).

Warming stimulated decomposition and nutrient turnover, resulting in higher $\mathrm{NH}_{4}^{+}$availability (Fig. 1). The higher microbial biomass $\mathrm{C}$ and $\mathrm{NH}_{4}^{+}$availability during summer 2007 is consistent with the increased mineralization with higher temperatures reported for wet sedge tundra and subalpine heath tundra (Schmidt et al., 2002; Schmidt et al., 1999; Jonasson et al., 1999). In general, northern high-latitude ecosystems are nutrient limited (Chapin, 1980; Vitousek and Howarth, 1991; Sistla et al., 2012) and are therefore expected to respond quickly to increased nutrient availability (Schmidt et al., 1999; Jonasson et al., 1999). Consistent with this nutrient (and temperature) limitation, we observed an increase in GPP during the extreme summer of 2007. However, in addition to GPP, $R_{\text {eco }}$ was also greater in summer 2007 than in other years, resulting in a NEE comparable to the previous colder and wetter summer. This is an important result, because while temperature increase and drought are well known to affect both GPP and $R_{\text {eco }}$ in wetlands (Shurpali et al., 1995; Arneth et al., 2002; Lafleur et al., 2003; Alm et al., 1999; Aurela et al., 2004; Lund et al., 2012), there are still large uncertainties about the impact of warming on the net $\mathrm{C}$ balance from tundra ecosystems (Ueyama et al., 2013). Overall, the similar net $\mathrm{CO}_{2}$ sink during the extreme summer 2007 showed that vascular plants were able to compensate for the lack of functionality of mosses. Since vascular plants absorb nitrogen from the soil (Chapin, 1980; von Wiren et al., 1997; Miller and Cramer, 2005), while mosses, lacking a developed rooting system, mostly rely on atmospheric deposition of $\mathrm{N}$ or $\mathrm{N}_{2}$ fixation by cyanobacteria (Vantooren et al., 1990; Solheim et al., 1996; Turetsky, 2003), it may be that the higher nitrogen availability in 2007 helped vascular plants to compensate for the reduced Sphagnum productivity during desiccation, at the same time as the lower water table limited $\mathrm{N}$ uptake by mosses (Ayres et al., 2006). A similar compensation was also observed in grassland ecosystems subjected to extreme events (Jentsch et al., 2011).

The unusually dry conditions of summer 2007 were associated with the shallowest thaw depth over the five-year record, despite the warmer temperatures. This is consistent 
with the lower soil moisture (Supplement Figs. S1 and S2) and lower water availability in the moss layer (Supplement Figs. S3 and S4) during this extreme summer. In fact, mosses tightly control the heat transfer into the soil by serving as an effective insulator when dry (Luthin and Guymon, 1974; Hinzman et al., 1991) but are good conductors during cold, wet periods, thereby allowing permafrost to exist where mean annual air temperatures are as high as $+2{ }^{\circ} \mathrm{C}$ (Jorgenson et al., 2010). The insulating properties of mosses when hot and dry can also decrease both annual and diurnal temperature fluctuations (Gornall et al., 2007; Nicolsky et al., 2007)

Contrary to our expectations, the minimum ecosystem $\mathrm{CO}_{2}$ sink and GPP were observed during the summer immediately following the extreme summer event. This is particularly surprising as arctic plants are well adapted to grow at low temperatures (Chapin, 1983, 1987; Koroleva, 1996). These results suggest that vascular plants experienced increased physiological activity in 2007 (Lichtenthaler, 1996) and might have had difficulties readjusting to the cooler, but typical, conditions after experiencing unusually warm temperatures (Marchand et al., 2005; Marchand et al., 2006b). This interpretation is consistent with the observed de-hardening (i.e., loss of heat and cold resistance) after exposure to extreme temperatures (Larcher, 2003; Marchand et al., 2006b). This de-hardening can follow both temperature extremes (i.e., low or high temperature) and might result in a decrease in both heat and cold resistance of arctic plants (Larcher, 2003; Marchand et al., 2006b; Bokhorst et al., 2011). A de-hardening might potentially explain the lowest GPP in the year following the extreme summer, with a return to colder temperatures. The observed negative lag effect, i.e., the reduced net $\mathrm{CO}_{2}$ sink and GPP in 2008, even with fairly typical summer air temperatures and precipitation, highlights the complexity of the response of this ecosystem to abnormal weather events. An alternative hypothesis is that during the extreme year, the increased mineralization rate and increased $\mathrm{N}$ availability resulted in increased GPP in vascular plants that offset the decreased moss GPP. But the following year, mosses had not yet recovered and GPP in vascular plants fell to typical levels, resulting in a decrease in stand GPP.

Lags in the response of net primary productivity (NPP) and $\mathrm{CO}_{2}$ uptake by vegetation to high irradiance and low rainfall have already been highlighted at the global scale (Keeling et al., 1996), including in high-latitude (Potter et al., 1999; Zhang et al., 2013) and subalpine ecosystems (Merbold et al., 2012). Biomass and community composition in tundra ecosystems can also show a lagged response to warming due to the soil moisture deficit lasting at least 3 months after the end of warming (Sherry et al., 2011). However, in our study, the soil moisture deficit in summer 2007 did not result in low soil moisture in summer 2008 (Fig. S2), suggesting that other mechanisms might have been responsible for the lowest $\mathrm{CO}_{2}$ uptake and GPP in the summer following the ex- treme event. In addition to the lag of ecosystem responses to climate variability, $R_{\text {eco }}$ might lag after increases in NPP in tundra ecosystems, most likely due to the dynamics of recalcitrant vs. labile $\mathrm{C}$ in the soil (Clein et al., 2002). However, in this C-rich wet-sedge tundra ecosystem, $R_{\text {eco }}$ presented a rapid response to warming (with the highest values in summer 2007).

The lowest over a five-year record GPP in 2008 might also be explained by the return of nutrients to lower concentrations while vegetation was still stressed by decreased carbohydrates reserves and mosses were affected by the desiccation experienced in summer 2007 (Supplement Fig. S5). The ecosystem proved to recover completely, at least in terms of its $\mathrm{C}$ balance, only two seasons after the extreme weather event, as shown by the similar NEE and GPP in summer 2009 and the summers of 2005 and 2006 (Fig. 3). The fact that the disturbance imposed on the system during the extreme year was only transitory and that a full recovery (at least in terms of NEE, and GPP) was observed in summer 2009 would imply that this wet-sedge tundra ecosystem is resilient to at least one isolated extreme event. However, additional longer-term studies are needed to investigate the impact of multiple subsequent extreme events and also potential changes in community composition after disturbances (Wu et al., 2011).

\section{Conclusions}

Responses of NEE, GPP, $R_{\mathrm{eco}}$, and NSE in Sphagnum imply that ecosystem $\mathrm{CO}_{2}$ sink strength in wet-sedge arctic tundra may not be immediately affected by extreme warm and clear summer weather (with high air temperatures, high evaporative demand, and low precipitation) such as in summer 2007. Instead, these wet sedge tundra ecosystems can exhibit a lag response where the decrease in $\mathrm{CO}_{2}$ sink strength does not occur until the following summer. Longer-term, comprehensive studies, are needed to refine our understanding of the processes responsible for this lag effect and to determine this ecosystem's ability to readjust (or not) to typical conditions after experiencing extreme weather events. Here, we showed that the ecosystem was able to recover its photosynthetic capacity just two years after the occurrence of an extreme event. However, this study encompassed five years and included only one extreme event. It may be that additional subsequent extreme events are much more damaging, and should be quantified by additional longer-term studies.

\section{The Supplement related to this article is available online at doi:10.5194/bg-11-5877-2014-supplement.}


Acknowledgements. We thank J. Verfaillie, R. Zulueta, H. Ikawa, P. Olivas, S. Oberbauer, and C. Tweedie for field, scientific, and technical assistance; G. Sheehan and the Barrow Arctic Science Consortium (BASC), UIC Science; C. Morales and CPS for logistic support; S. Hastings for his help in the management of the experiment; M. Reichstein and O. Menzer for help in the gap-filling and uncertainty analysis of the EC data; I. Nijs for the scientific discussion; and Frances Byrnes for editing the manuscript. The research was conducted on land owned by the Ukpeagivik Iñupiat Corporation (UIC). This work was funded by the Biocomplexity Program, Environment-Coupled Biogeochemical Cycles, and by the Office of Polar Programs of the National Science Foundation (NSF) (award no. 0421588), and would not have been possible without logistics support funded by the NSF Office of Polar Programs. Preparation of this paper was supported by the Carbon in Arctic Reservoirs Vulnerability Experiment (CARVE), an Earth Ventures (EV-1) investigation, under contract with the National Aeronautics and Space Administration and by NSF grant (award no. 1204263). We thank the EU for providing funding for traveling (Short-Term Scientific Mission - STSM) and for support of discussions on data analysis (COST Action ABBA ES0804). This manuscript benefited from the careful revision of three reviewers. Finally, we thank the EU Carbo-Extreme team for very helpful scientific discussions.

Edited by: M. Bahn

\section{References}

Alm, J., Schulman, L., Walden, J., Martikainen, P. J., and Silvola, J.: Carbon balance of a boreal bog during a year with an exceptionally dry summer, Ecology, 80, 161-74, 1999.

Angert, A., Biraud, S., Bonfils, C., Henning, C. C., Buermann, W., Pinzon, J., Tucker, C. J., and Fung, I.: Drier summers cancel out the $\mathrm{CO}_{2}$ sink enhancement induced by warmer springs, P. Natl. Acad. Sci. USA, 102, 10823-10827, 2005.

Arneth, A., Kurbatova, J., Kolle, O., Shibistova, O., Lloyd, J., Vygodskaya, N., and Schulze, E.-D.: Comparative ecosystematmosphere exchange of energy and mass in a European Russian and a central Siberian bog II. Interseasonal and interannual variability of $\mathrm{CO}_{2}$ fluxes, Tellus B, 54, 514-30, 2002.

Aurela, M., Laurila, T., and Tuovinen, J.-P.: The timing of snow melt controls the annual $\mathrm{CO}_{2}$ balance in a subarctic fen, Geophys. Res. Lett., 31, L16119, doi:10.1029/2004GL020315, 2004.

Ayres, E., van der Wal, R., Sommerkorn, M., and Bardgett, R. D.: Direct uptake of soil nitrogen by mosses, Biol. Lett., 2, 286-288, doi:10.1098/rsbl.2006.0455, 2006

Billings, W. D., Luken, J.O., Mortensen, D. A. and Peterson, K. M.: Arctic tundra: A source or sink for atmospheric carbon dioxide in a changing environment?, Oecologia, 53, 7-11, 1982.

Bokhorst S, Bjerke, J. W., Street, L. E., Callaghan, T. V., and Phoenix, G. K.: Impacts of multiple extreme winter warming events on sub-Arctic heathland: phenology, reproduction, growth, and $\mathrm{CO}_{2}$ flux responses, Glob. Change Biol., 17, $2817-$ 2830, 2011.

Bokhorst, S., Huiskes, A., Aerts, R., Convey, P., Cooper, E. J., Dalen, L., Erschbamer, B., Gudmundsson, J., Hofgaard, A., Hollister, R. D., Johnstone, J., Jónsdóttir, I. S., Lebouvier, M., Van de Vijver, B., Wahren, C.-H., and Dorrepaal, E.,: Variable tem- perature effects of Open Top Chambers at polar and alpine sites explained by irradiance and snow depth, Glob. Change Biol., 19, 64-74, 2013.

Brown, J.: Tundra soils formed over ice wedges, northern Alaska, Soil Sci. Soc. Am. Pro., 31, 686-691, 1967.

Brown, J., Hinkel, K. M., and Nelson, F. E.: The circumpolar active layer monitoring (CALM) program: Research designs and initial results, Polar Geogr., 24, 166-258, 2000.

Chapin, F. S.: The Mineral-Nutrition of Wild Plants, Annu. Rev. Ecol. Syst., 11, 233-260, doi:10.1146/annurev.es.11.110180.001313, 1980.

Chapin III, F. S.: Direct and indirect effects of temperature on arctic plants, Polar Biol., 2, 47-52, 1983.

Chapin III, F. S.: Environmental controls over growth of tundra plants, Ecol. Bull., 38, 69-76, 1987.

Chen, J. M., Chen, B., Higuchi, K., Liu, J., Chan, D, Worthy, D., Tans, P. and Black, A.: Boreal ecosystems sequestered more carbon in warmer years, Geophys. Res. Lett., 33, L10803, doi:10.1029/2006g1025919, 2006.

Clein, J. S., Kwiatkowski, B. L., McGuire, A. D., Hobbie, J. E., Rastetter, E. B., Melillo, J. M., and Kicklighter, D. W.: Modelling carbon responses of tundra ecosystems to historical and projected climate: a comparison of a plot- and a global-scale ecosystem model to identify process-based uncertainties, Glob. Change Biol., 6, 127-140, 2000.

Dorrepaal, E., Toet, S., van Logtestijn, R. S. P., Swart, E., van de Weg, M. J., Callaghan, T. V., and Aerts, R.: Carbon respiration from subsurface peat accelerated by climate warming in the subarctic, Nature, 460, 616-619, 2009.

Elmendorf, S. C., Henry G. H. R, Hollister, R. D., Bjork, R. G., Bjorkman, A. D., Callaghan, T. V., Collier, L. S., Cooper, E. J., Cornelissen, J. H. C., Day, T. A., Fosaa, A. M., Gould, W. A., Gretarsdottir, J., Harte, J., Hermanutz, L., Hik, D. S., Hofgaard, A., Jarrad F. Jonsdottir, I. S., Keuper, F., Klanderud K., Klein, J. A., Koh, S., Kudo, G., Lang, S. I, Loewen, V., May, J. L., Mercado, J., Michelsen, A., Molau, U., Myers-Smith I. H., Oberbauer S. F., Pieper S., Post, E., Rixen, C., Robinson, C. H., Schmidt, N. M., Shaver, G. R., Stenstrom, A., Tolvanen, A., Totland, O., Troxler, T., Wahren C. H., Webber, P. J., Welker, J. M., and Wookey, P. A.: Global assessment of experimental climate warming on tundra vegetation: heterogeneity over space and time, Ecol. Lett., 15, 164-175, 2012.

Epstein, H. E., Raynolds, M. K., Walker, D. A., Bhatt, U. S., Tucker, C. J., and Pinzon, J. E.: Dynamics of aboveground phytomass of the circumpolar Arctic tundra during the past three decades, Environ. Res. Lett., 7, 015506 doi:10.1088/1748-9326/7/1/015506, 2012.

Gerdol, R. and Vicentini, R.: Response to heat stress of populations of two Sphagnum species from alpine bogs at different altitudes, Environ. Exp. Bot., 74, 22-30, doi:10.1016/j.envexpbot.2011.04.010, 2011.

Gornall, J. L., Jónsdóttir, I. S., Woodin, S. J., and Van der Wal, R.: Arctic mosses govern belowground environment and ecosystem processes, Oecologia, 153, 931-941, 2007.

Harazono, Y., Mano, M., Myiata, A., Yoshimoto, M., Zulueta, R. C., Vourlitis, G. L. Kwon, H., and Oechel, W. C.: Temporal and spatial differences of methane flux at arctic tundra in Alaska, Mem, Natl. Inst. Polar Res. Spec. Issue Jpn., 59, 79-95, 2006. 
Harley, P. C., Tenhunen, J. D., Murray, K. J., and Beyers, J.: Irradiance and temperature effects on photosynthesis of tussock tundra Sphagnum mosses from the foothills of the Philip Smith mountains, Alaska, Oecologia, 79, 251-259, doi:10.1007/bf00388485, 1989.

Hinkel, K. M., Paetzold, R. F., Nelson, F. E., and Bockheim, J. G.: Patterns of soil temperature and moisture in the active layer and upper permafrost at Barrow, Alaska: 1993-1999, Global Planet. Change, 29, 293-309, 2001.

Hinzman, L. D., Kane, D. L., Benson, C. S., and Everett, K. R.: Hydrologic and thermal properties of the active layer in the Alaskan Arctic, Cold Reg. Sci. Technol., 19, 95-110, 1991.

Hsieh, C. I., Katul, G., and Chi, T.: An approximate analytical model for footprint estimation of scalar fluxes in thermally stratified atmospheric flows, Adv. Water Res., 23, 765-772, 2000.

IPCC: Summary for Policymakers. In: Climate Change 2013: The Physical Science Basis. Contribution of Working Group I to the Fifth Assessment Report of the Intergovernmental Panel on Climate Change, edited by: Stocker, T. F., Qin, D., Plattner, G.-K., Tignor, M., Allen, S. K., Boschung, J., Nauels, A., Xia, Y., Bex, V., and Midgley, P. M., Cambridge University Press, Cambridge, United Kingdom and New York, NY, USA, 2013.

Jentsch, A., Kreyling, J., and Beierkuhnlein, C.: A new generation of climate-change experiments: events, not trends, Front. Ecol. Environ., 5, 365-374, 2007.

Jentsch, A., Kreyling, J., Elmer, M., Gellesch, E., Glaser, B., Grant, K., Hein, R., Lara, M., Mirzae, H., Nadler, S. E., Nagy, L., Otieno, D., Pritsch, K., Rascher, U., Schädler, M., Schloter, M., Singh, B. K., Stadler, J., Walter, J., Wellstein, C., Wöllecke, J., and Beierkuhnlein C.: Climate extremes initiate ecosystemregulating functions while maintaining productivity, J. Ecol., 99, 689-702, 2011.

Jonasson, S., Michelsen, A., and Schmidt, I. K.: Coupling of nutrient cycling and carbon dynamics in the Arctic, integration of soil microbial and plant processes, Appl. Soil Ecol., 11, 135-146, 1999.

Jones, B. M., Kolden, C. A., Jandt, R. R., Abatzoglou, J. T., Urban, F., and Arp, C. D. : Fire behavior, weather, and burn severity of the 2007 Anaktuvuk River tundra fire, North Slope, Alaska, Arct. Antarct. Alp. Res., 41, 309-316, doi:10.1657/1938-424641.3.309, 2009.

Jorgenson, M. T., Romanovsky, V., Harden, J., Shur, Y., O’Donnell, J., Schuur, E. A. G., Kanevskiy, M., and Marchenko, S.: Resilience and vulnerability of permafrost to climate change, Can. J. Forest Res., 40, 1219-1236, 2010.

Keeling, C. D., Chin, J. F. S., and Whorf, T. P.: Increased activity of northern vegetation inferred from atmospheric $\mathrm{CO}_{2}$ measurements, Nature, 382, 146-149, 1996.

Kljun, N., Calanca, P., Rotach, M. W., and Schmid H. P.: A simple parameterisation for flux footprint predictions, Bound.-Lay. Meteorol., 112, 503-523, 2004.

Koroleva, O. Y.: Cold acclimation of the photosynthetic apparatus in an arctic species, Oxyria digyna, Russ. J. Plant Physiol., 43, 319-324, 1996.

Lafleur, P. M., Roulet, N. T., Bubier, J. L., Frolking, S., and Moore, T. R.: Interannual variability in the peatland-atmosphere carbon dioxide exchange at an ombrotrophic bog, Glob. Biogeochem. Cy., 17, 1036-1049, 2003.
Larcher, W.: Physiological plant ecology. Ecophysiology and stress physiology of functional groups, Heidelberg, Berlin, Germany, Springer-Verlag, 2003.

Lasslop, G., Reichstein, M., Papale, D., Richardson, A. D., Arneth, A., Barr, A., Stoy, P., and Wohlfahrt, G.: Separation of net ecosystem exchange into assimilation and respiration using a light response curve approach, critical issues and global evaluation, Glob. Change Biol., 16, 187-208, 2010.

Lichtenthaler, H. K.: Vegetation Stress: an Introduction to the stress concepts in plants, J. Plant Physiol., 148, 4-14, 1996.

Liljedahl, A. K., Hinzman, L. D., Harazono, Y., Zona, D., Tweedie, C., Hollister, R. D., Engstrom, R., and Oechel, W. C.: Nonlinear controls on evapotranspiration in arctic coastal wetlands, Biogeosciences, 8, 3375-3389, doi:10.5194/bg-8-3375-2011, 2011.

Lipson, D. A., Zona, D., Raab, T. K., Bozzolo, F., Mauritz, M., and Oechel, W. C.: Water-table height and microtopography control biogeochemical cycling in an Arctic coastal tundra ecosystem, Biogeosciences, 9, 577-591, doi:10.5194/bg-9-577-2012, 2012.

Lund, M., Christensen, T. R., Lindroth, A., and Schubert, P.: Effects of drought conditions on the carbon dioxide dynamics in a temperate peatland, Environ. Res. Lett., 7, 045704 , doi:10.1088/1748-9326/7/4/045704, 2012.

Luthin, J. N. and Guymon, G. L.: Soil moisture-vegetationtemperature relationship in central Alaska, J. Hydrol., 23, 233246, 1974.

Marchand, F. L., Mertens, S., Kockelbergh, F., Beyens, L., and Nijs, I.: Performance of High Arctic tundra plants improved during but deteriorated after exposure to a simulated extreme temperature event, Glob. Change Biol., 11, 2078-2089, doi:10.1111/j.13652486.2005.01046.x, 2005.

Marchand, F. L., Verlinden, M., Kockelbergh, F., Graae, B. J., Beyens, L., and Nijs I.: Disentangling effects of an experimentally imposed extreme temperature event and naturally associated desiccation on Arctic tundra, Funct. Ecol., 20, 917-928, 2006 a.

Marchand, F. L., Kockelbergh, F., Van De Vijver, B., Beyens, L., and Nijs, I.: Are heat and cold resistance of arctic species affected by successive extreme temperature events?, New Phytol., 170, 291300, 2006b.

Merbold, L., Rogiers, N., Eugster, W.: Winter $\mathrm{CO}_{2}$ fluxes in a subalpine grassland in relation to snow cover, radiation and temperature, Biogeochemistry, 111, 287-302, 2012.

Miller, A. J. and Cramer, M. D.: Root nitrogen acquisition and assimilation, Plant Soil, 274, 1-36, doi:10.1007/s11104-004-0965$1,2005$.

Monteith, J. L.: Vegetation and the atmosphere, vol. 1: Principles, Academic Press, London, 1975.

Nicolsky, D. J., Romanovsky, V. E., Alexeev, V. A., and Lawrence, D. M.: Improved modeling of permafrost dynamics in a GCM land-surface Scheme, Geophys. Res. Lett., 34, L08501, doi:10.1029/2007GL029525, 2007.

Oechel, W. C.: Seasonal patterns of temperature response of $\mathrm{CO}_{2}$ flux and acclimation in arctic mosses growing in situ, Photosynthetica, 10, 447-456, 1976.

Oechel, W. C., Hastings, S. J., Vourlitis, G. L., Jenkins, M., Riechers, G., and Grulke, N.: Recent change of arctic tundra ecosystems from a net carbon sink to a source, Nature, 361, 520-526, 1993. 
Oechel, W. C., Vourlitis, G. L., Hastings, S. J., and Bochkarev, S. A.: Change in Arctic $\mathrm{CO}_{2}$ flux-over two decades: Effects of climate change at Barrow, Alaska, Ecol. Appl., 5, 846-855, 1995.

Oechel, W. C., Laskowski, C. A., Burba, G., Gioli, B., and Kalhori, A. A. M.: Annual patterns and budget of $\mathrm{CO}_{2}$ flux in an Alaskan arctic tussock tundra ecosystem at Atqasuk, Alaska, J. Geophys. Res., 119, 323-339, doi:10.1002/2013JG002431, 2014.

Olivas, P. C., Oberbauer, S. F., Tweedie, C., Oechel, W. C., and Kuchy, A.: Responses of $\mathrm{CO}_{2}$ flux components of Alaskan Coastal Plain tundra to shifts in water table, J. Geophys. Res., 115, G00I05, doi:10.1029/2009jg001254, 2010.

Olivas, P. C. Oberbauer, S. F., Tweedie, C. Oechel, W. C., Lin, D., and Kuchy, A.: Effects of Fine-Scale Topography on $\mathrm{CO}_{2}$ Flux Components of Alaskan Coastal Plain Tundra: Response to Contrasting Growing Seasons, Arct. Antarct. Alp. Res., 43, 256-266, 2011.

Perkins, S. E., Alexander, L. V., and Nairn, J. R.: Increasing frequency, intensity and duration of observed global heatwaves and warm spells, Geophys. Res. Lett., 39, L20714, doi:10.1029/2012GL053361, 2012.

Peterson, K. M., Billings, W. D., and Reynolds, D. N.: Influence of Water Table and atmospheric $\mathrm{CO}_{2}$ Concentration on the Carbon Balance of Arctic Tundra, Arct. Antarct. Alp. Res., 16, 331-335, 1984.

Piao, S., Ciais, P., Friedlingstein, P., Peylin, P., Reichstein, M., Luyssaert, S., Margolis, H., Fang, J., Barr, A., Chen, A., Grelle, A., Hollinger, D. Y., Laurila, T., Lindroth, A., Richardson, A. D., and Vesala, T.: Net carbon dioxide losses of northern ecosystems in response to autumn warming, Nature, 451, 49-52, 2008.

Potter, C. S., Klooster, S., and Brooks, V.: Interannual Variability in Terrestrial Net Primary Production: Exploration of Trends and Controls on Regional to Global Scales, Ecosystems, 2, 36-48, 1999.

Price, J., Edwards, T. W. D., Yi, Y., and Whittington, P. N.: Physical and isotopic characterization of evaporation from Sphagnum moss, J. Hydrol., 369, 175-182, 2009.

Reichstein, M., Falge, E., Baldocchi, D., Papale, D., Aubinet, M., Berbigier, P., Bernhofer, C., Buchmann, N., Gilmanov, T., Granier, A., Grünwald, T., Havránková, K., Ilvesniemi, H., Janous, D., Knohl, A., Laurila, T., Lohila, A., Loustau, D., Matteucci, G., Meyers, T., Miglietta, F., Ourcival, J.-M., Pumpanen, J., Rambal, S., Rotenberg, E., Sanz, M., Tenhunen, J., Seufert, G., Vaccari, F., Vesala, T., Yakir, D., and Valentini, R.: On the separation of net ecosystem exchange into assimilation and ecosystem respiration, review and improved algorithm, Glob. Change Biol., 11, 1424-1439, 2005.

Riutta, T., Laine, J., and Tuittila, E.-S.: Sensitivity of $\mathrm{CO}_{2}$ exchange of fen ecosystem components to water level variation, Ecosystems, 10, 718-733, 2007.

Runkle, B. R. K., Sachs, T., Wille, C., Pfeiffer, E.-M., and Kutzbach, L.: Bulk partitioning the growing season net ecosystem exchange of $\mathrm{CO}_{2}$ in Siberian tundra reveals the seasonality of its carbon sequestration strength, Biogeosciences, 10, 1337-1349, doi:10.5194/bg-10-1337-2013, 2013.

Schmidt, I. K., Jonasson, S., and Michelsen, A.: Mineralization and microbial immobilization of $\mathrm{N}$ and $\mathrm{P}$ in arctic soils in relation to season, temperature and nutrient amendment, Appl. Soil Ecol., 11, 147-160, 1999.
Schmidt, I. K., Jonasson, S., Shaver, G. R., Michelsen, A., and Nordin, A.: Mineralization and distribution of nutrients in plants and microbes in four arctic ecosystems: responses to warming, Plant Soil, 242, 93-106, 2002.

Sheffield, J., Wood, E. F., and Roderick, M. L.: Little change in global drought over the past 60 years, Nature, 491, 435-438, 2012.

Sherry, R. A., Zhou, X. H., Gu, S. L., Arnone, J. A., Johnson, D. W., Schimel, D. S., Verburg, P. S. J., Wallace, L. L., and Luo, Y. Q.: Changes in duration of reproductive phases and lagged phenological response to experimental climate warming, Plant Ecol. Divers., 4, 23-35, 2011.

Shurpali, N. J., Verma, S. B., Kim, J., and Arkebauer, T. J.: Carbon dioxide exchange in a peatland ecosystem, J. Geophys. Res., 100, 14319-14326, 1995.

Sistla, S. A., Asao, S., and Schimel, J. P.: Detecting microbial Nlimitation in tussock tundra soil: implications for Arctic soil organic carbon cycling, Soil Biol. Biochem., 55, 78-84, 2012.

Solheim, B., Endal, A., and Vigstad, H.: Nitrogen fixation in Arctic vegetation and soils from Svalbard, Norway, Polar Biol., 16, 3540, 1996.

Sturtevant, C. S., Oechel, W. C., Zona, D., Kim, Y., and Emerson, C. E.: Soil moisture control over autumn season methane flux, Arctic Coastal Plain of Alaska, Biogeosciences, 9, 1423-1440, doi:10.5194/bg-9-1423-2012, 2012.

Tieszen, L. L., Miller, P. C., Lewis, M. C., Mayo, J., Chapin III, F. S., and Oechel, W. C.: An analysis of processes of primary production in tundra growth forms, in: Tundra ecosystems: a comparative analysis, edited by: Bliss L. C., Heal O. W., and Moore J. J., Cambridge Univ. Press, 285-356, 1981.

Turetsky, M. R.: Bryophytes in carbon and nitrogen cycling, New Frontiers in Bryology and Lichenology, The Bryologist, 106, 395-409, 2003.

Ueyama, M., Iwata, H., Harazono, Y., Euskirchen, E. S., Oechel, W. C., and Zona, D.: Growing season and spatial variations of carbon fluxes of Arctic and boreal ecosystems in Alaska (USA), Ecol Appl., 8, 1798-1816, 2013.

Vantooren, B. F., Vandam, D., and During, H. J.: The Relative Importance of Precipitation and Soil as Sources of Nutrients for Calliergonella-Cuspidata (Hedw) Loeske in Chalk Grassland, Funct. Ecol., 4, 101-107, 1990.

Vavrus, S., Holland, M. M., Jahn, A., Bailey, D. A., and Blazey, B. A.: Twenty-First-Century Arctic climate change in CCSM4, J. Climatol., 25, 2696-2710, doi:10.1175/JCLI-D-11-00220.1, 2012.

Vitousek, P. M. and Howarth R. W.: Nitrogen Limitation on Land and in the Sea - How Can It Occur?, Biogeochemistry, 13, 87115, 1991.

von Wiren, N., Gazzarrini, S., and Frommer, W. B.: Regulation of mineral nitrogen uptake in plants, Plant Soil, 196, 191-199, doi:10.1023/a:1004241722172, 1997.

Walker, M. D., Wahren, C. H.,Hollister, R. D., Henry, G. H. R., Ahlquist, L. E., Alatalo, . M., Bret-Harte, M. S., Calef, M. P., Callaghan, T. V., Carroll, A. B., Epstein, H. E., Jónsdóttir, I. S., Klein, J. A., Magnússon, B.,Molau, U., Oberbauer, S. F., Rewa, S. P., Robinson, C. H., Shaver, G. R., Suding, K. N., Thompson, C. C., Tolvanen, A., Totland, Ø., Turner, P. L., Tweedie, C. E., Webber, P. J., and Wookey, P. A.: Plant community responses to 
experimental warming across the tundra biome, P. Natl. Acad. Sci. USA, 103, 1342-1346, 2006.

Webb, E. K., Pearman, G. I., and Leuning, R.: Correction of flux measurements for density effects due to heat and water vapour transfer, Q. J. R. Meteorol. Soc., 106, 85-100, doi:10.1002/qj.49710644707, 1980.

Wilson, W.: Observations on the temperatures of arctic plants and their environment, J. Ecol., 45, 499-531, 1957.

Wookey, P. A., Aerts, R., Bardgett, R. D., Baptist, F., Bråthen, K. A., Cornelissen, J. H. C., Gough, L., Hartley, I. P., Hopkins, D. W., Lavorel, S., and Shaver, G. R.: Ecosystem feedbacks and cascade processes: understanding their role in the responses of arctic and alpine ecosystems to environmental change, Glob. Change Biol., 15, 1153-1172; doi:10.1111/j.1365-2486.2008.01801.x, 2009.

Wu, Z., Dijkstra, P., Koch, G. W., Peñuelas, J., and Hungate, B. A.: Responses of terrestrial ecosystems to temperature and precipitation change: a meta-analysis of experimental manipulation, Glob. Change Biol., 17, 927-942, doi:10.1111/j.13652486.2010.02302.x, 2011.

Yang, D., Goodison, B. E., and Ishida, S.: Adjustment of daily precipitation data of 10 climate stations in Alaska: Applications of world meteorological organization intercomparison results, Water Resour. Res., 34, 241-256, 1998.

Zhang, X., Gurney, K. R. , Peylin, P., Chevallier, F., Law, R. M., Patra, P. K., Rayner, P. J., Röedenbeck, C., and Krol, M.: On the variation of regional $\mathrm{CO}_{2}$ exchange over temperate and boreal North America, Global Biogeochem. Cy., 27, 991-1000, doi:10.1002/gbc.20091, 2013.
Zhao, M. and Running, S. W.: Drought-Induced Reduction in Global Terrestrial Net Primary Production from 2000 through 2009, Science, 329, 940-943, doi:10.1126/science.1192666, 2010.

Zhou, L. M., Tucker, C. J., Kaufmann, R. K., Slayback, D., Shabanov, N. V., and Myneni, R. B.: Variations in northern vegetation activity inferred from satellite data of vegetation index during 1981 to 1999, J. Geophys. Res. 106, 20069-20083, 2001.

Zona, D., Oechel, W. C., Kochendorfer, J., Paw U, K. T., Salyuk, A. N., Olivas, P. C., Oberbauer, S. F., and Lipson, D. A.: Methane fluxes during the initiation of a large-scale water table manipulation experiment in the Alaskan Arctic tundra, Global Biogeochem. Cy., 23, GB2013, doi:10.1029/2009GB003487, 2009.

Zona, D., Oechel, W. C., Richards, J. H., Hastings, S., Kopetz, I., Ikawa, H., and Oberbauer, S.: Light-stress avoidance mechanisms in a Sphagnum-dominated wet coastal Arctic tundra ecosystem in Alaska, Ecology, 92, 633-644, doi:10.1890/100822.1, 2011.

Zona, D., Lipson, D. A., Paw U, K. T., Oberbauer, S. F., Olivas, P., Gioli, B., and Oechel, W. C.: Increased $\mathrm{CO}_{2}$ loss from vegetated drained lake tundra ecosystems due to flooding, Global Biogeochem. Cy., 26, GB2004, doi:10.1029/2011gb004037, 2012. 